\title{
SURF TOURISM DEVELOPMENT: PERSPECTIVES IN ALAÇATI SURF SPOT
}

Murat NAZLI ${ }^{1}$

Rasim Muzaffer MUSAL ${ }^{2}$
Received Date (Başvuru Tarihi): 02/06/2018

Accepted Date (Kabul Tarihi): 25/06/2018

Published Date (Yayın Tarihi): 02/09/2018

\begin{abstract}
The main objective of this research is to analyze and evaluate the perceptions and opinions of employees and visitors on sustainable surf tourism in seven surf centers in a popular tourism destination called Alaçatı, Turkey. Based on the interviews in seven schools by using the semi-structured interview technique, research findings revealed that construction and housing around the surf destination should be limited and natural texture should be preserved in the bay area. Formation of surf camps for kids from various age groups are critical for the development of surf tourism industry. Innovative windsurf related activities should be organized to attract the attention of domestic and international visitors. This exploratory research sheds a light in this field of study for researchers, practitioners and sports tourism professionals.
\end{abstract}

Keywords: Surf Tourism, Wind-Surfing, Surf Development

JEL Codes: L83, Z31, Z32

\section{SÖRF TURİMI GELIŞiMI: ALAÇATI SÖRF NOKTASINDAKİ PERSPEKTİFLER}

\section{ÖZ}

Araştırmanin temel amacl, popüler bir turizm destinasyonu olan Alaçatl, Türkiye'deki yedi sörf merkezinde çalı̧̧anların ve ziyaretçilerin sürdürülebilir sörf turizmi hakkındaki fikirlerini ve algılarını değerlendirmek ve analiz etmektir. Yart-yapılandırılmış mülakat tekniği kullanılarak yedi okul içerinde yapılmış mülakatlar temelinde, araştırma sonuçları şunları ortaya koymaktadır; Sörf destinasyonunda inşaat ve yerleşim alanı sinırlı olmalıdır ve koydaki doğal doku korunmalıdır. Sörf turizm endüstrisinin gelişimi için farkl yaş gruplarından olan çocukların olduğu sörf kamplarının oluşumu kritiktir. Yerel ve uluslararası ziyaretçilerin dikkatini çekmek için yenilikçi rüzgar sörfü ile ilgili faaliyetler organize edilmelidir. Bu keşifsel araştırma, bu alanda çalışan araştırmacılara, uygulayıcılara ve sporla ilgili turizm profesyonellerine ışık tutmaktadır.

Anahtar Kelimeler: Sörf Turizmi, Rüzgar Sörfü, Sörf Gelişimi

JEL Kodlart: L83, Z31, Z32

\footnotetext{
${ }^{1}$ Lecturer Dr., Yaşar University, nazli.murat@gmail.com

${ }^{2}$ Assoc. Prof. Rasim Muzaffer Musal, Texas State University, mmusal@gmail.com
} 


\section{INTRODUCTION}

Recently, the conventional holiday perception has given place to different holiday types. Accordingly, it is expected that sport tourism will increasingly become essential. Sport tourism also makes progress day by day since it provides people to be active socially; provides personal and self-confidence developments. Within the adventure/sport tourism sector, surf tourism has become a significant market (Doering, 2018; Buckley et al., 2017; Barbieri \& Sotomayor, 2013). However, the global surf tourism industry has grown significantly since the middle of the 20th century (Brochado et al., 2018; Sotomayor \& Barbieri, 2016; Ponting \& McDonald, 2013; Martin \& Assenov, 2011b).

Today, surf tourism has grown tremendously and is represented by several markets (Doering, 2018; Ponting \& McDonald, 2013). Current trends in surf tourism include experienced surfers travelling to locations such as Hawaii, South Africa, Indonesia and Western Australia to experience high quality, large waves. Intermediate level surfers travelling to stay at surf schools where coaching, lessons and access to equipment and other activities may be found; or beginner level surfers looking to get lessons in a safe, small wave environment where crowds are minimal and instructors help the beginners professionally (Martin \& Assenov, 2011).

In recent years, surfing has made progress in Turkey. Many domestic and international tourists have visited various destinations so as to perform the sport tourism in which they are interested. One destination for Turkey that is highly popular for surfers is Alaçatı, Çeşme. It has been thought that Alaçatı is the most favorable region in that it is a closed cove, safe, with shallow water and adequate wind (Yenilmez \& Çelik, 2017; Avcı \& Barışık, 2015; Dalgakıran $\&$ Bal, 2007). Favorable geographic characteristics of the destination in terms of windsurf causes the worldwide surf lovers to recognize this destination as an ideal spot.

Windsurf schools which provide training to the domestic and international tourists create the infrastructure of this sport. The destination which is preferred by many domestic and foreign windsurfers becomes an essential center with the national and international organizations of windsurf. These are; Windsurf League, Alaçatı Surf Festival, Pegasus Airlines PWA Windsurf World Cup, IFCA Surf World Championship, European Championship, Jim Beam Windsurf World Championship and Mistral Windsurf World Championship (Avcı \& Barış1k, 2015). What makes this study unique is that after the coup attempt in the country in 2016, the social and economic impacts on surf tourism are mainly investigated in this tourism destination, along with the first hand data through surf centers. Accordingly, the primary aim 
of this exploratory research is to analyze and evaluate the perception and opinion of employees and visitors on surf tourism development in a globally known tourism destination called Alaçatı. A semi-structured interview technique is used with the participants from seven surf centers throughout the peak season.

\section{LITERATURE REVIEW}

Started with the independent travelers searching for new surfing spots, surf tourism peaked in the 1960s due to more affordable air transportation, lighter surfboards and the image of a surfing culture delivered through media, increased accessibility to lessons at surf camps (Brochado et al., 2018; Barbieri \& Sotomayor, 2013; Ng et al., 2013; Tantamjarik, 2004). Surf tourism takes place in thousands of coastal locations from Iceland to Antarctica (Ponting, 2009). Although surf tourism is a globally expanding market segment, limited material has been published with reference to the field of study (Martin \& Assenov, 2011a). Crowded urban surf breaks in surfers' home countries drive demand for surf tourism to areas offering high quality waves and uncrowded conditions (Hugues Dit Ciles, 2009; Ponting, 2008; Dolnicar \& Fluker, 2003; Preston-Whyte, 2002). At least 38 surf travel guidebooks include 112 of 161 countries known to host surfing tourists (Martin \& Assenov, 2011a) from a global surfer population estimated to be between 20 (Lazarow \& Nelson, 2007) to 25 million (Aguerre, 2009). Surf tourism features travel for the purposes of surfing, learning to surf, or attending a surfing activity. Recent estimates of the global surfer population are 35 million participants (O'Brien $\&$ Eddie, 2013). As Krause (2012) stated one of the essential differences between surf tourists and other travelers is that surfers stay longer and prefer local establishments more often than other types of tourists. Lately, recreational surfing and surf tourism have emerged as multibillion dollar industries including equipment manufacturers, clothing firms, amateur and professional sporting events, domestic and international tourism (Martin \& Assenov, 2014). In addition, surf sites and surfing activities play a leading role in a region's image, commerce and tourism-based identity (Doering, 2018; Martin, 2013). For example, owners and tourism officials reported that surfers were environmentally minded, sensitive to natural environment and on balance who had a minimal impact on the coastal ecologies (Krause, 2012). This is another issue why surf tourism is important for creating sustainable tourism activities and services. 
The literature on surf tourism has fundamentally put emphasis on community influences, urbanization problem and entrepreneurial activities in surf tourism locations (Martin \& Assenov, 2012). Previous surf tourism studies have explored the sustainability of management plans, regulations and policies in various destinations (Martin \& Assenov, 2014; O’Brien \& Ponting, 2013; Buckley, 2002). Moreover, researchers have investigated the economic impact of surf breaks using travel cost and ecosystem services methodologies (Margules, 2011; Coffman \& Burnett, 2009; Lazarow \& Nelson, 2007), performance assessment across genders (Eurich et al., 2010), effects of surfing events (Ahmed et al., 2008; Getz \& Fairley, 2003), medical matters such as injuries related to surfing (Hay et al., 2009; Carrasco, 2008) and attachment to surf spots (Reineman \& Ardoin, 2018). Barbieri and Sotomayor (2013)'s research was conducted with a sample of 126 surfers to examine whether six leisure qualities (effort, ethos, identity, career, benefits, perseverance) are associated with surf travel behavior and destination choices. Moreover, Martin and Assenov (2012) reviewed surf tourism studies between years 1997-2011 and expressed; surfing events, artificial surfing reefs, sustainability of surf spots and host communities are among the most prolific areas under discussion and key debates contain socioeconomics, sustainable tourism and coastal management.

In recent years, surfing has also made progress in Turkey. Many individuals have visited different destinations in order to perform the sport tourism in which they are interested. One destination for Turkey that is enduringly popular for surfers is Alaçatı. International surfing destinations are highly dependent on specific combinations of wind-wave formation, thermal conditions and local bathymetry (Espejo et al., 2014). The geographic features of the region are so favorable for windsurf activities (Yenilmez \& Çelik, 2017; IZKA, 2014; Dalgakıran \& Bal, 2007; Sönmez, 2006). Buckley (2002) stated that people are willing to pay for unique surfing experiences in uncrowned and exotic locations. Alaçatı has competitive advantages in the niche market of surf tourism industry with these mentioned characteristics.

Based on the research of Alkan (2015), all participants agreed the most appealing asset of Alaçatı is the surf tourism with its favorable wind and surf beaches. The participants stated that good blowing wind, safe deepness and available spots for training of water attract the visitors in the destination as well. In the study of Avcı and Barışı (2015), based on the interviews with managers of eight surf schools, they said that they contribute to the region in terms of promotion, economy, employment and incoming tourist number. The distinguishing characteristics of surf centers located here from other schools have been listed as: the safety of 
bay, shallowness of water, visibility of the bottom of sea and existence of constant wind. The biggest threat for visitors coming for sun, sea and sand is the wind turbines that are going to be built. They have stated that increasing the number of feasts and having them in low season would increase the number of surfers and extend the tourism season. What makes this research different from other recent studies (Yenilmez \& Çelik, 2017; Avcı \& Barışık, 2015) is that after the coup attempt in the country in the summer 2016, the social and economic influences on surf tourism are researched, along with the collection of first hand data source.

\section{THEORETICAL BACKGROUND}

The view for sport organizations has changed and moved toward new business models and functions. The most important changes in sport management landscape influenced some areas. These are; movement from performance responsibility to shared responsibility for performance (engagement of internal stakeholders, internal vision), dynamic and complex perspective of management, constant pressure to provide better performance through better quality services and products, continuous improvement of standards, integrity and sustainability of operations (Tortora, 2018: 302). These characteristics refer to the paradigm shift that occurred in the second half of the last century, also in business and management sciences. Modern contributions to this management thinking came apparently from systems approach (von Bertalanffy, 1979), network theory and stakeholder theory (Freeman, 1984), contingency theory and learning organization theory (Senge, 1990).

According to contingency theory, there is no universal or one best way to manage and the theory focuses on the organization's capacity to adapt to new situations and requirements (Laxton, 2017). Systems theory (von Bertalanffy, 1979) and network theories recognize the importance of factors and events occurring outside the organization and in the surrounding environment (Tortora, 2018: 301). In this study, understanding the situations of surf centers, opinions of staff members and visitors in Alaçatı will provide a clear perspective of the inside and outside factors influencing the tourism destination. By using the systems, contingency and stakeholder theories, the adaptation of these theories to the development of surf tourism in the researched destination form the basis of this study. Understanding the operations of surf centers in which inside factors (duties of personnel, quality of personnel, use of technology, objectives of centers) and outside factors (domestic and international visitors, market conditions and price policies, competition, government incentives, socio-cultural conditions, construction firms) play a significant role in their sustainability. Considering the contingency theory and systems theory perspective, paying attention to the sub-systems inside the surf centers and relation 
between these sub-systems and the tourism environment is essential for taking sustainable actions for the future. Understanding the characteristics of businesses and sectors, knowing organizational strengths and dependencies will influence the survival of organizations (Laxton, 2017). By this way, comprehending the business environment of surf centers and links between other sectors in the region will help the centers survive and position themselves in the longterm.

Throughout the interviews, investigation of the opinions of the internal stakeholders of the surf centers (managers, staff members, surf instructors) and external stakeholders (surfers, visitors, community participation) will be crucial in understanding the sustainable perspectives of surf tourism within the destination. As Byrd (2007) stated that the involvement of community and community based tourism development in the surf areas will increase the tourism potential of the surf destination. The top priority should be to preserve and promote touristic resources in order to develop the competitive advantage (Liu, 2003), especially greener advantage (Aktas $\&$ Atrek, 2015) of the destination.

\section{METHOD}

\subsection{Purpose of Research}

The fundamental purpose of this research is to analyze and evaluate the professional perception and opinion of employees and visitors on the subject of surf tourism development in seven different surf centers out of ten contacted surf schools in a globally known tourism destination called Alaçat. The secondary aim is to understand the sustainability of the business activities of the surf schools in the destination, after the coup attempt which happened in 2016 in Turkey.

\subsection{Sample and Method}

The sample size consists of 66 participants including managers, administrative personnel, surf instructors, trainees and visitors in one of the world's best windsurf regions where large and best-equipped watersports and activity centers exist within the bay area. However, the appropriate responses after the final data gathering period is 64 . Throughout the research, a semi-structured interview technique is used to gather data from the participants in the surf centers. Ten questions are asked to the personnel and visitors within a questionnaire. The surf clubs are well-equipped in terms of number and quality of equipment, land size and several services besides windsurfing such as; stand up paddling, kitesurfing, sea kayak, biking, yoga, massage, basketball, volleyball, grass soccer, beach, restaurants, shopping stores and kids 
activities with various languages. Data are gathered from the participants at the end of three months (from the beginning of June 2017 - until the end of August 2017) which is the peak season. It is assumed to be the most crowded destination especially during this time of the year in day time in the surf region. The data include the responses of employees, managers inside the surf club, self and visitor observations, short talks with the employees, surf instructors and visitors within the data collection period. It approximately took 30 minutes to take the responses from each participant at noon in the peak day time. In other words, the interaction time with participants who accept to answer the questions about the development of surf tourism took at least 1920 minutes in total.

\subsection{Credibility of Data}

It is essential that all researchers attempt "to avoid as much error as possible during all phases of research so as to increase the credibility of results" (Brink, 1989). To attain credibility, the study must be valid and reliable which is a challenge when it is based on a semistructured interview (Louise \& While, 1994). However, considering the average surfing experience of the participants (7.7 years), evaluation of professionals, surfers, and the vast majority of participants who work in the surf centers for a long time as a manager, surf instructor and other key staff members, the gathered data from first hand in this tourism spot is credible.

\subsection{Research Questions}

Ten questions are asked to the participants including the demographic characteristics (age group, gender, main duties of staff members in the surf school and surfing experience in years or just the visitors of the surf destination). The core questions, excluding the demographics are as follows;

- What are the general purposes and secondary purposes of the visitors in the surf centers in the destination?

- How do the recent economic fluctuations in Turkey and their effects on the tourism industry affect the surf centers in the destination?

- How is the development of surf tourism in the region and in the bay area?

- How do you see the future of surf centers for the next 15 years considering the service approach, the number of surf centers, the quality of equipment, and the technological advances in surf industry?

- Can you make a comparison between the surf centers in the destination and the other centers around the world in terms of their services, operating activities, entrepreneurial or innovative efforts within the provided services? 


\section{RESULTS}

\subsection{Demographics and Sample Structure}

Table 1 states the demographic factors of participants within the surf centers. Average age of respondents is 32 . Average age of female is 33.2 and average age of male is 31.3. Besides the other staff members, the customers and windsurf instructors within the facility form the main sample. In addition, the average experience of participants is more than seven years which means the respondents are pretty knowledgeable about the surf related matters.

\begin{tabular}{lcc} 
Table 1: Demographics & Respondent & Percentage (\%) \\
\hline Gender & $n(64)$ & 100 \\
Female & 21 & 32.8 \\
Male & 43 & 67.2 \\
Age & $n(64)$ & \\
Average age (Female): 33.2 & 21 & 32.8 \\
Average age (Male): 31.3 & 43 & 67.2 \\
Average age: $\quad 32$ & & \\
Participant Characteristics & $n(64)$ & 100 \\
Customer & 19 & 29.6 \\
Instructor & 16 & 25 \\
Receptionist & 5 & 7.8 \\
Surfer & 5 & 7.8 \\
Runner & 4 & 6.2 \\
Trainee & 4 & 6.2 \\
Manager & 3 & 4.6 \\
Sales & 3 & 4.6 \\
(Assistant instructor, Kids camp staff, & 5 & 8.0 \\
National sailmaker, Captain, Accounting) & & \\
Surfing Experience (in years) & $n(64)$ & 100 \\
Average experience: 7.7 & 64 & \\
& &
\end{tabular}

\subsection{General and Secondary Purpose Of Visitors}

All of the participants agreed that the general aim of visitors in the destination is for vacation, pleasure and travel reasons. None of the respondents mentioned visiting their family, friends or neighbors or business related activities for their general aim of visit to the tourism destination. Table 2 presents secondary aims of participants based on 64 responses. Although the research question asks the secondary purpose of visitors to the area excluding surfing, the respondents gave emphasis on surfing in the first place. The second most important factor is stated as sun, sea and sand. The least essential factor is stressed as other activities such as paddle board, stand up paddling, biking etc. 
Table 2: Secondary Aims Of Visitors

\begin{tabular}{|l|c|c|}
\multicolumn{1}{|c|}{ Expressions } & Frequency & \% of expressions \\
\hline (1) Surfing & 46 & 71.8 \\
\hline (2) Sun, sea, sand & 31 & 48.4 \\
\hline (3) Restaurant, cafe, bar & 33 & 51.5 \\
\hline (4) Yoga, massage & 24 & 37.5 \\
\hline (5) Basketball, volleyball & 29 & 45.3 \\
\hline $\begin{array}{l}\text { (6) Other activities (paddle board, stand up paddling } \\
\text { and kitesurf rentals, gym, fitness, biking, sunbath) }\end{array}$ & 40 & 62.5 \\
\hline
\end{tabular}

(1): the most important factor; (6): the least important factor

\subsection{Influences Of Economic Fluctuations On Tourism And Surf Centers}

Table 3 emphasizes the expressions mentioned by the respondents about the influences of economic fluctuations on tourism industry and the surf centers. The top two expressions expressed by the respondents are the decline in the number of foreign visitors and excessive prices.

Table 3: Effects Of Economic Fluctuations On Tourism And Surf Centers

\begin{tabular}{|l|c|c|}
\hline \multicolumn{1}{|c|}{ Expressions } & Frequency & \% of expressions \\
\hline Decrease in number of foreign tourists & 14 & 15.6 \\
\hline High prices & 10 & 10.9 \\
\hline Negative & 7 & 7.8 \\
\hline Real surfers not affected & 5 & 6.3 \\
\hline Reservation cancellations & 4 & 6.3 \\
\hline Local tourists not affected & 4 & 4.7 \\
\hline Decrease in number of courses and rentals & 3 & 3.1 \\
\hline Too many construction and housing & 2 & \\
\hline
\end{tabular}

The following factors are stated by the respondents only one time; Necessary government and tourism policy, decrease in number of students, this sustainable sport will continue to exist. Clearly, 52 respondents are pessimistic about the impacts of economic fluctuations on tourism and surf establishments. The respondents thought that the decrease in number of tourists, cancelled reservations, high accommodation and rental prices, increase in number of construction sites and housing and influence of them in the natural environment have a significant impact in the survival of the surf centers. 
Only nine respondents are optimistic. They stated that local surf lovers are not affected with these fluctuations. Three respondents do not have clear answers. A 24 year old female receptionist stated that "The travel agents are calling us to get the confirmation whether it is safe in Alaçatı during this period of summer time. We try to persuade lots of international visitors that it's safe here." A 23 year old female windsurf trainer expressed that "Number of foreign customers visiting the surf centers fairly reduced. There were reservation cancellations made by overseas travel agencies. Ratio of local customers continues more or less the same. Our center provides price reductions to continue its profitability.” A 34 year old experienced male instructor mentioned that "The region is affected negatively. Windsurf participants in this region are formed by middle and upper middle level income earners. Continuity of this income group is essential." A 73 year old female visitor addressed that "Prices are still high in the region and accommodation in boutique hotels can be better. It is good that surf centers have other activities."

\subsection{Emphasized Factors To Develop The Surf Tourism In The Region}

Table 4 addresses the factors that can be proposed to develop the surf tourism industry in the bay area, based on 62 responses. The top three highly mentioned responses are respectively; the use of advertisement channels (domestic, international and social media tools) efficiently and effectively, reduction of constructions (hotels and housing) and setting affordable lodging prices to promote surf tourism. 
Table 4: Factors To Develop Surf Tourism In The Region

\begin{tabular}{|l|c|c|}
\hline \multicolumn{1}{|c|}{ Expressions } & Frequency & \% of expressions \\
\hline Advertisement (local, international, social media) & 16 & 25 \\
\hline No construction (hotel, housing) necessary & 12 & 18.7 \\
\hline Affordable accommodation price & 11 & 17.1 \\
\hline Promotion & 9 & 14.0 \\
\hline Protection of natural environment in the region & 8 & 12.5 \\
\hline Improvement of surf related activities & 6 & 9.3 \\
\hline Improving standards of surf schools & 5 & 7.8 \\
\hline Taking competitive races sustainably & 5 & 7.8 \\
\hline Activities for kids & 4 & 6.2 \\
\hline Government support, incentives for surf schools & 4 & 6.2 \\
\hline Opening new surf hubs to the region & 3 & 4.7 \\
\hline Affordable food and beverage price & 2 & 3.1 \\
\hline Increase the quality of training and equipment & 2 & 3.1 \\
\hline
\end{tabular}

The following factors are stated by the respondents only once. Improving caravan tourism, being professional, making people conscious about surfing, finding ways to extend surf season, forming a council of federation from experienced surfers, auditing of government, enhancing the infrastructure work, cooperating with other surf schools abroad, remembering Alaçatı brand. The staff members and visitors stated several factors that can develop the surf tourism in the area. For instance, a 52 year old female accounting staff expressed that "There has to be government incentives, a federation should be established, beaches and bays should be closed to construction industry. Only for coastal areas which are disposed for revenue, should be opened to windsurf related sports. A 39 year old experienced male surfer believed that "Density of wind, construction will affect wind quality. Wind turbines affect the wind intensity due to an energy transfer from one place to another. In previous years, wind was generally around 15 knot, right now is 15-30 knot." A 20 year old female staff stated that "Prices should be set fairly, activities should be prepared that can be promoted to international visitors. Promotions should be prepared for nightclubs so that people wake up early and go surfing, price reductions are essential." A 73 year old female customer believed that "Advertisement in internet, visuals, and films should exist thus increase demand, cooperation 
with groups and surf schools abroad. Students can travel between surf regions as a member of sister school through a student exchange program."

\subsection{Future Of Surf Centers For The Next 15 Years}

Table 5 shows the opinions of staff and visitors about the surf centers for the next 15 years, based on 60 responses. 32 respondents are pessimistic about the future due to several reasons such as increase in construction, price levels, lack of advertisement, conservation of the environment and coastal areas etc.

Table 5: Future Of Surf Centers For The Next 15 Years

\begin{tabular}{|c|c|c|}
\hline Expressions & Frequency & $\%$ of expressions \\
\hline (-) Constructions & 8 & 13.3 \\
\hline Decline in number of tourists & 6 & 10 \\
\hline More advertisement and promotion needed & 6 & 10 \\
\hline Protection of natural environment (coast) & 4 & 6.7 \\
\hline Expensive price policy, rentals and housing & 3 & 5 \\
\hline In need of political stability & 2 & 3.3 \\
\hline (+) Equipment, services in development & 6 & 10 \\
\hline Continuing and developing high standards & 5 & 8.3 \\
\hline Kids activities & 4 & 6.7 \\
\hline Experienced and qualified staff & 3 & 5 \\
\hline Increase in number of surfers & 3 & 5 \\
\hline Training quality & 2 & 3.3 \\
\hline
\end{tabular}

(-): pessimist perspective; (+): optimistic perspective

The following pessimist factors are stated by the respondents only once; Expansion of marina and yacht traffic, visitors coming for entertainment but not sports, hotels and night clubs affecting negatively. The following optimistic factors are stated only once; Chain hotels in touch with surf schools, kitesurf opportunity, opportunity for caravan tourism in region, new talents coming out, increased awareness of parents. Several staff members and visitors stressed different views about the future expectations of the region. For example, a 28 year old male receptionist said that "I predict a decline in incoming foreign surfers. Due to obligation of reducing costs, there will be a decline in service quality. Due to expensive prices of renting, courses, there will be reduction in number of starters and surfers." A 34 year old male instructor in one surf school in the region expressed that "In the next 15 years, balance between 
windsurf participant/surf center management will not be damaged. Some surf centers might end operations. Equipment technology will not change very much. If political tension lowers, more foreign tourists will visit." A 20 year old female sales staff addressed that "Surf is promoted by media every day. There is an increase in awareness of parents along with small-aged kids camps held in schools. We see kids who are surfers. This will increase the popularity." A 40 year old male sailmaker stated that "Kitesurf can be alternative to surf, easier to learn. There is no production facility for surf equipment in Turkey but production requires detailed research, development and engineering. There will be an increase in number of kite-surfers."

\subsection{Surf Centers In Alaçatı Compared To Others In The World}

Table 6 presents the opinions of staff and visitors and comparisons are made with other surf centers around the world, but 17 respondents did not answer the question. Based on 47 responses, the evaluations vary based on their level of experience in surf industry. However, 19 percent of the respondents have a high opinion of the tourism destination by stating its ranking in the world.

Table 6: Surf Centers In Alaçatı Compared To Others In The World

\begin{tabular}{|l|c|c|}
\hline \multicolumn{1}{|c|}{ Expressions used for Alaçatı } & Frequency & \% of expressions \\
\hline Alaçatı is ranked as the 2nd best spot in the world & 9 & 19.1 \\
\hline Have not been any surf center abroad & 7 & 12.9 \\
\hline Better equipment and satisfactory & 6 & 8.5 \\
\hline Concerned instructors, helpfulness, staff effort & 4 & 8.5 \\
\hline Innovative activities should be increased & 3 & 6.4 \\
\hline Better in quality and service & 3 & 6.4 \\
\hline Compact facilities & 3 & 6.4 \\
\hline Better in safety and training & 2 & 4.3 \\
\hline Low respect to nature & 4 & \multirow{2}{*}{6.5} \\
\hline
\end{tabular}

The following factors are stated only once; increasing construction and housing, high price, better architecture, great wind and shallow water, transformation of surf centers into a living space with activities and surf camps for kids, and lacking training of instructors for developing their skills during work time

Some of the staff members and a visitors pointed out various perspectives about the surf region. For instance, a 28 year old male reservation staff stressed that "Based on comparisons of our visitors, we have compact facilities (restaurant, cafe, showers, basketball courts etc.) in 
Alaçatı as compared to surf centers abroad. The other topic mentioned is that our employees are more helpful." A 28 year old female trainer stated that "There is an innovative approach but the surf season should extend to six-seven months from two months and work should be done accordingly. The biggest problem is the shortness of the season." A 20 year old female receptionist emphasized that "Our main difference is along with summer schools, every year we train 150 little surfers per school and we increase the efficiency in this sport." An experienced 40 year old male surfer stated that "There is a worldwide tournament in MauiHawaii. Distance to city center is $200 \mathrm{~km}$. Surfers are gathered by minibuses, taken to spots. Nature is protected. Planners are very attentive. In Turkey, it is opposite, constructions keep increasing." In relation with the stakeholder theory, cooperating closely with the local authorities, and the community, understanding and anticipating the needs of domestic and international visitors, and surf enthusiasts who benefit from this surf destination is crucial for the development of this sport. Managing the contingencies and adapting to changes in the surf spot, taking corrective actions to preserve the nature, understanding the processes in surf centers and improving the systems of operations towards the protection of resources are pivotal for the survival of this sport.

\section{DISCUSSION}

Various participants from different backgrounds, gender, age groups and experience levels in surf tourism industry took place in this exploratory research. This type of variety brought several point of views in comprehending the tendencies in windsurf activities, evaluating and analyzing the innovative approaches. Based on the interview outcomes, the main findings are expressed under five main headings.

\section{Natural Environment}

The construction sites and housing around the surf region should be limited. The quality of wind and water is crucial for the destination (Lopes \& Bicudo, 2017). The natural texture or habitat should be preserved and respected attentively (Nazl1, 2016) in the bay area. Otherwise, too many construction activities ignoring the flora, fauna, quality of wind, and ecologically vulnerable areas will destroy the surfing spots in the long-term.

\section{Staff and Quality}

There is a need of experienced personnel if not, well-trained, knowledgeable staff with managerial skills (Nazl1, 2017: 232) is necessary for the representation of the surf centers, region and surf industry. Paying attention to internal stakeholders is vital for the continuation 
of surf centers. Setting the quality standards for the schools and sustaining them in the long-run are pivotal for the sustainability of surf industry (Brochado et al., 2018).

\section{Activities}

Considering the systems theory and network theory, recognizing the essentiality of factors and events happening outside the surf centers and in the surrounding environment is paramount in taking corrective action in a timely manner. Cooperation with other schools abroad, other student groups, kid groups from different ages and connection with the chain hotels is essential for the expansion of surf tourism in the region. The surf related innovative activities or other supportive sports activities should be presented throughout the day and the season to the visitors to attract more attention to the surf region. The international competitions should be taken continuously within the bay area. The promotional tactics and long-term perspectives should be formed to boost surf tourism. Taking advantage of government support or incentives is essential to stimulate surf tourism industry. While paying attention to surf tourism, trying to boost other nature related tourism activities such as caravan tourism, trekking, camping etc. will support the surf industry indirectly. Along with these activities, paying attention to the amount of carbon footprint (Nazl1, 2013: 303; Nazl1, 2013a: 266) of visitors or investors will increase the awareness of preservation of nature.

\section{Price Policy}

Fair price policy of surf centers for equipment rentals or purchases should be reestablished carefully for the domestic and international tourists. Although the surf centers try to survive in this competitive business environment, as stated in the interviews, along with the affordable prices of the surf activities, trying to make the local or international visitors feel that they are home and comfortable, is essential. The visitors also would to feel like the paid amount is worth for the activity. In addition, according to Rendle and Rodwell (2014), planning should include a contingency for cost of maintenance or removal if there is lack of proper service.

\section{Seasonality Problem}

Taking into account the contingency theory, one of the main perspectives of surf centers in the destination should be focusing on their capacity or ability to adapt to new conditions and requirements throughout the season. Searching for ways, building and applying long-term strategies to extend the surf season from two months to twelve months is critical. Seminars especially for parents should be organized in order to make them have an influence on kids so that the kids will be willing to come to surf camps throughout the whole season. Innovative 
windsurf related activities should be organized to attract the attention of visitors throughout the year. The main reasons of the pessimist views of sustainability of surf tourism should be carefully evaluated, ways be found to extend the length of stays. According to Dalgakiran and Bal (2007), Lopes and Bicudo (2017), there are a number of factors that should be paid attention. These are not violating the coastline, not destructing the ecological balance, not damaging the ovulation areas of fish and birds, reevaluating the construction projects, considering the objections or opinions of environmental groups and professional associations. Similarly, Yaşar (2014) stressed that settlement affects negatively the quality of surf wind.

\section{CONCLUSIONS AND FURTHER RESEARCH}

In this exploratory research, the main purpose was to analyze and assess the perception and opinion of employees, managers and visitors on surf tourism development along with 64 participants in seven surf centers out of ten contacted surf schools in a popular tourism destination. What actually makes this exploratory study unique is that;

- The study includes a theoretical perspective including stakeholder theory, contingency theory and systems theory.

- After the coup attempt in the country in the summer 2016, the social and economic influences on surf tourism are investigated in 2017 in this tourism destination.

- Several stakeholder point of views such as surf instructors, employees, managers and visitors took place within the surf schools.

- Along with the semi-structured interview technique, data were gathered in the peak season in the surf destination.

- The gathered information can be taken into consideration to ensure suggestions to local authorities who make policy decisions for future developments of the region.

- The outcome of this research will convey knowledge for other tourism spots and will contribute to the literature of sport tourism.

The destination owns a great accumulation with its historical wealth, geographical resources, sectoral diversity in the axis of agriculture-tourism-housing. This accumulation should not be consumed by projects with the sole aim of profit and ignoring the environmental factors and sustainability. There has to be an establishment of widened tourism policies that stress the environmental sensitivity, socio-cultural fit between visitors and the community, conservation of natural and historical resources which will determine the future success (IZKA, 2014; Dalgakiran \& Bal, 2007). In order to cultivate tourism in the region; all tourism-related establishments (non-governmental organizations, private industry representatives, municipal 
administrators) should work together. The critical point is that it should be decided upon whether Alaçatı is desired to be made into an outstanding surf spot or not (Avcı \& Barışık, 2015). Throughout the interviews, the study is also backed up by the theoretical frame depending on several instances. Working together with other stakeholders such as surf schools in the destination or abroad in relation with the entrepreneurial activities, especially involving the community, local authorities in surf areas (stakeholder theory) will be essential. Widening tourism policies to increase the awareness about natural environment in today's competitive world is another matter to reconsider. Keeping the operations sustainable depending on current political, financial and environmental situations, taking corrective actions (contingency theory) and understanding sub-systems inside the organizations and outside surf schools (systems theory) will also be critical to sustain the operations and to provide this sport activity to future generations. The study also comes with some limitations. It is an exploratory and qualitative study trying to understand and analyze the perception of professionals and visitors in the surf industry in one surf destination. Only seven surf centers are investigated for research purposes. Due to the nature of the research and difficulty in gathering data in the peak season, the sample size consists of a limited number of respondents. The research gives a certain point of view of professionals and surf lovers but generalizing the findings is very difficult due to the sample size. For the future studies, empirical research can be performed by considering indicators in surf tourism literature and bringing several perspectives to the surf centers. By considering other types of adventure/nature tourism, a study can be performed by paying attention to the supporting activities within the windsurf region such as biking, hiking, climbing, surfboard and kids activities within different age groups via schools. Entrepreneurial tendencies of surf tourists as similar to the study of (Ratten, 2018) or entrepreneurial activities of surf centers can be analyzed as well. 


\section{REFERENCES}

Aguerre, F. (2009). A surfer at the Olympic Congress in Denmark. Retrieved from <http://www.isasurf.org/newsletter/31/en/31.html>.

Ahmed, F., Moodley, V., \& Sookrajh, R. (2008). The environmental impacts of beach sport tourism events: A case study of the Mr. Price Pro Surfing, Durban, South Africa. Africa Insight, 38(3), 73-85.

Aktas, G., \& Atrek, B. (2015). Sports As A Green Product In Destination Marketing: Case Of Windsurfing in Cesme, Turkey. Journal of Yaşar University, 10(39), 6596-6606.

Alkan, C. (2015). Sürdürülebilir Turizm: Alaçatı Destinasyonuna Yönelik Bir Uygulama. Journal of Yaşar University, 10(40), 6692-6710.

Avcı, N., \& Barışık, M. Ş. (2015). The Importance of Windsurf Schools in Tourism: The Case of Alaçatı. Journal of Yaşar University, 10(37), 6381- 6477.

Barbieri, C., \& Sotomayor, S. (2013). Surf Travel Behavior and Destination Preferences: An Application of the Serious Leisure Inventory and Measure. Tourism Management, 35, 111-121.

Brink P. J. (1989). Issues in reliability and validity. In Qualitative Nursing Research: A Contemporary Dialogue (Morse J.M. ed.), Aspen, Rockville, Maryland.

Brochado, A., Stoleriu, O., \& Lupu, C. (2018). Surf camp experiences. Journal of Sport \&Tourism, 1-21.

Buckley, R. C., Guitart, D., \& Shakeela, A. (2017). Contested surf tourism resources in the Maldives. Annals of Tourism Research, 64, 185-199.

Buckley, R. (2002). Surf Tourism and Sustainable Development in Indo Pacific Island. Journal of Sustainable Tourism, 10(5), 405-424.

Byrd, E. T. (2007). Stakeholders in sustainable tourism development and their roles: applying stakeholder theory to sustainable tourism development. Tourism Review, 62(2), 6-13.

Carrasco, A. (2008). Effects of exercise-induced dehydration on cognitive ability, muscular endurance and surfing performance (Master's thesis). Massey University, Auckland, New Zealand.

Coffman, M., \& Burnett, K. (2009). The value of a wave: An analysis of the Mavericks Region, Half Moon Bay, California. San Francisco: Save the Waves Coalition.

Dalgakıran, A., \& Bal, E. (2007). Alaçatı'da Mekansal ve Toplumsal Farklılıklar Üzerinde Yükselen Farklı Turizm Eğilimleri. Ege Coğrafya Dergisi, 16, 53-67.

Doering, A. (2018). Mobilising Stoke: A Genealogy of Surf Tourism Development in Miyazaki, Japan. Tourism Planning \& Development, 15(1), 68-81.

Dolnicar, S., \& Fluker, M. R. (2003). The symptomatic nature of past destination choice among surf tourists. Paper presented at the Council of Australian University Tourism and Hospitality Educators (CAUTHE) 5-8th February 2003, Coffs Harbour).

Espejo, A., Losada, I. J., \& Méndez, F. J. (2014). Surfing Wave Climate Variability. Global and Planetary Change, $121,19-25$.

Eurich, A., Brown, L., Coburn, J., Noffal, G., Nguyen, D., Khamoui, A., \& Uribe, B. (2010). Performance differences between sexes in the pop-up phase of surfing. Journal of Strength \& Conditioning Research, 24(10), 2821-2825.

Freeman, R. E. (1984). Strategic Management: A Stakeholder Approach. Boston: Pitman.

Getz, D., \& Fairley, S. (2003). Media management at sport events for destination promotion: Case studies and concepts. Event Management, 8(3), 127-139.

Hay, C., Barton, S., \& Sulkin, T. (2009). Recreational surfing injuries in Cornwall, UK. Wilderness and Environmental Medicine, 20(4), 335-338.

Hugues Dit Ciles, E. K. (2009). The sustainability of surfing tourism at remote destinations. Unpublished doctoral dissertation, University of Plymouth, Plymouth, UK.

IZKA - Izmir Development Agency (2014). Yarımada Sürdürülebilir Kalkınma Stratejisi 2014-2023. Retrieved from http://www.izmiriplanliyorum.org/static/upload/file/yarimada_kalkinma_stratejisi.pdf 
Krause, S. M. (2012). Pilgrimage to the Playas Surf Tourism in Costa Rica. Anthropology in Action, 19(3), 37-48.

Laxton, D. M. (2017). Creating A Competitive Advantage Through Strategic Thinking. Journal of Research in Business, Economics and Management, 8(6), 1596-1604.

Lazarow, N., \& Nelson, C. (2007). The value of coastal recreational resources: A case study approach to examine the value of recreational surfing to specific locales, in: Proceedings of Coastal Zone 07, July 22-26, Portland, OR.

Liu, Z. (2003). Sustainable Tourism Development. Journal of Sustainable Tourism, 11(6), 459-474.

Lopes, J. T., \& Bicudo, P. (2017). Surfing Tourism Plan: Madeira Island Case Study. European Journal of Tourism Research, 16, 45-56.

Louise B. K., \& While, A. (1994). Collecting Data using a semi-structured interview: a discussion paper. Journal of advanced nursing, 19(2), 328-335.

Margules, T. (2011). Understanding the Roles of Ecosystem Services in the Local Economy of Uluwatu, Bali, Indonesia. (BSc. Hons), Southern Cross University.

Martin, S. A., \& Assenov, I. (2014). Investigating the Importance of Surf Resource Sustainability Indicators: Stakeholder Perspectives for Surf Tourism Planning and Development. Tourism Planning \& Development, 11(2), 127-148.

Martin, S. A. (2013). A Surf Resource Sustainability Index for Surf Site Conservation and Tourism Management. Thesis Submitted in Fulfillment of the Requirements for the Degree of Doctor of Philosophy in Environmental Management, Prince of Songkla University.

Martin, S. A., \& Assenov, I. (2012). The Genesis of a New Body of Sport Tourism Literature: A Systematic Review of Surf Tourism Research (1997-2011). Journal of Sport and Tourism, 17(4), 257-287.

Martin, S. A., \& Assenov, I. (2011a). A statistical analysis of surf tourism research literature. Paper presented at the 4th Annual PSU Research Conference: Multidisciplinary Studies on Sustainable Development, Prince of Songkla University, Phuket Campus, Thailand.

Martin, S. A., \& Assenov, I. (2011b). Beach and Coastal Survey of Thailand: What Future for Surf Tourism. Journal of Tourism, Hospitality \& Culinary Arts, 3(1), 77-87.

Nazlı, M. (2017). Managing People. Ige Pırnar, Evla Kesici, Melih Tütüncüoğlu \& Metehan İğneci (Eds.), In International Services Marketing (pp. 231-236). Ankara: Detay

Nazl1, M. (2016). Does Sustainability Matter? A Qualitative Study in Tourism Industry in Turkey. Journal of Yaşar University, 11(44), 339-350.

Nazlı, M. (2013). Carbon Footprint. Çagrı Bulut \& Ige Pirnar (Eds.), In Uluslararası Işsletmecilik: Temel Kavramlar (pp. 303-310). Ankara: Nobel.

Nazlı, M. (2013a). Kyoto Protocol. Çagrı Bulut \& Ige Pırnar (Eds.), In Uluslararası Işsletmecilik: Temel Kavramlar (pp. 266-271). Ankara: Nobel.

Ng, K., Phillips, M. R., Calado, H., Borges, P., \& Veloso-Gomes, F. (2013). Seeking Harmony in Coastal Development for Small Islands: Exploring Multifunctional Artificial Reefs for São Miguel Island, the Azores. Applied Geography, 44, 99-111.

O’Brien, D., \& Eddie, I. (2013). Benchmarking global best practice: Innovation \& leadership in surf city tourism and industry development. Keynote presentation at the Global Surf Cities Conference.

O’Brien, D., \& Ponting, J. (2013). Sustainable Surf Tourism: A Community Centered Approach in Papua New Guinea. Journal of Sport Management, 27, 158-172.

Ponting, J., \& McDonald, M. (2013). Performance, agency and change in surfing tourist space. Annals of Tourism Research, 43, 415-434.

Ponting, J. (2009). Projecting paradise: The surf media and the hermeneutic circle in surfing tourism. Tourism Analysis, 14(2), 175-185.

Ponting, J. (2008). Consuming Nirvana: An exploration of surfing tourist space. Unpublished doctoral dissertation, University of Technology, Sydney, Australia.

Preston-Whyte, R. (2002). Constructions of surfing space at Durban, South Africa. Tourism Geographies, 4(3), 307-328. 
Ratten, V. (2018). Entrepreneurial intentions of surf tourists. Tourism Review. Retrieved from https://doi.org/10.1108/TR-05-2017-0095

Reineman, D. R., \& Ardoin, N. M. (2018). Sustainable tourism and the management of nearshore coastal places: place attachment and disruption to surf-spots. Journal of Sustainable Tourism, 26(2), 325-340.

Rendle, E. J., \& Rodwell, L. D. (2014). Artificial surf reefs: A preliminary assessment of the potential to enhance a coastal economy. Marine Policy, 45, 349-358.

Senge, P. (1990). The fifth discipline: the art and practice of the learning organization. Academic press.

Sönmez, U. (2006). Rüzgar Sörfünün Yayılması Açısından, Sörf Tüketicisinin Profilinin Belirlenmesi Ve Sörf Okullarının Önemi. Celal Bayar Üniversitesi, SBE, Beden Ĕ̆itimi Öğretmenliği, Sporda Psiko-Sosyal Alanlar Bilim Dall, Yüksek Lisans Tezi.

Sotomayor, S., \& Barbieri, C. (2016). An exploratory examination of serious surfers: Implications for the surf tourism industry. International Journal of Tourism Research, 18(1), 62-73.

Tantamjarik, P. (2004). Sustainability Issues Facing the Costa Rica Surf Tourism Industry (Master thesis). University of Hawaii, HA.

Tortora, M. (2018). Sport Management and Sustainability Innovation Challenges. Sports Media, Marketing, and Management: Breakthroughs in Research and Practice: Breakthroughs in Research and Practice, 301.

von Bertalanffy, L. (1979). General System Theory, reprint, 1968, Braziller, New York.

Yaşar, O. (2014). Bozcaada'nın Su Sporlarından Rüzgar Sörfü (Windsurfing) ve Uçurtma Sörfü (Kitesurfing) Potansiyelinin Coğrafi Temelleri. Turkish Studies - International Periodical For The Languages, Literature and History of Turkish or Turkic, 9(2), 1643-63.

Yenilmez, M. İ., \& Çelik, O. B. (2017). Competing For Waves: The Unjust Reality Of Women’s Position In The World of Surfing. Spor ve Performans Araştırmaları Dergisi, 8(1), 63-74. 